\title{
Legal Framework for Financial Regulation in the RF as a Factor in Ensuring the Economic Security of the Russian Arctic
}

\author{
Kondratovich D. L. \\ Federal Research Center "Kola Science Center of the Russian Academy of Sciences", \\ Apatity, Russia, \\ k_dim@iep.kolasc.net.ru
}

\begin{abstract}
The article analyzes certain provisions of financial regulation, subject to the amendments to the Budget Code of the Russian Federation. The possibilities of effective financial regulation with a view to ensuring the economic security of the Russian Arctic are assessed. It has been determined that the organization of measures aimed at ensuring control and supervision functions over the compliance with the budgetary management procedure eventually makes it possible to use budgetary funds more efficiently and economically, to explore possibilities for using internal reserves of an organization, to increase the level of financial discipline and the sustainability of the economic system as a whole, which ultimately has a positive effect on ensuring the economic security of the constituent entities of the Russian Federation. This article presents an analysis of the main violations in the implementation of financial control (using the example of an Arctic region - the Murmansk region), which indicates the lack of proper control by public authorities or local self-government bodies, that distribute budgetary funds, regarding their compliance with internal procedures and standards affecting a number of aspects of budget reporting, as well as control and audit of subordinate recipients of budget funds. The article describes the role of financial regulation as a condition for the rational use of state (municipal) and other monetary funds through the application of efficiency and effectiveness principles. The article concludes that the Budget Code should reflect legal norms that make it possible to define the responsibility of certain individuals for violations revealed as a result of financial control more clearly.
\end{abstract}

Keywords - Legal framework, financial regulation, financial control, economic security, Arctic

\section{INTRODUCTION}

In part, ensuring the economic security of the Russian Arctic is implemented through financial regulation, which is implemented by public authorities of the Russian Federation. Such regulation is implemented, first of all, at the macro level and is aimed at preventing threats related to the destabilization of the financial sector of the economy, as well as through minimizing negative tendencies that affect the formation and development of the financial system in the Arctic regions of the Russian Federation, which are more vulnerable to changes in the economic environment due to their natural, economic, and geographical features.

In general, the state of financial security of the Arctic regions depends on the general level of the economic security and sustainability of the financial sector. Instability in the work of financial institutions can lead to the emergence of threats related to the financial security of both the Arctic regions in particular, and the state as a whole, since this can lead to the impossibility of ensuring sustainability in meeting the financial interests of business structures and the population.

In this regard, some of the most significant factors that may have a negative impact on the level of economic security of the Russian Arctic should be considered in detail. Such factors include, in particular, the legal framework for the implementation of financial regulation in the Russian Federation, which determines the procedure for the application of certain measures of influence against subjects of law.

In order to obtain reliable scientific results, within the framework of this article, a system approach, which provides the possibility of using a number of parameters allowing to increase the efficiency and effectiveness of financial regulation, a method of theoretical generalization, content analysis of the legislative and regulatory framework, as well as a monographic method were applied. Foreign researches by several authors in the field of studying the economic and financial aspects of economic security were analyzed: Hager W. [1], Murdoch C. [2], Jiang Y. [3], Guro L. [4], Neu C. R. [5], Ocepek A. [6], Theriou G. N. [7]. Based on materials of such Russian researchers as Abalkin L. I. [8], Glazyev S. Yu. [9], Tatarkin A. I. [10], [11], Selin V. S. [12], Ulchenko M. V. [13], [14], Badylevich R. V. [15], [16], Kozmenko S. Yu [17], and a number of others [18], the main aspects of financial regulation as a factor in ensuring the economic security of the Russian Arctic were identified.

\section{RESEARCH PURPOSE AND OBJECTIVES}

The purpose of the study is to examine the features of the legal framework for the implementation of financial regulation in the Russian Federation in order to reduce external and 
internal threats to the economic security of the Russian Arctic and ensure the financial security of the state.

To ensure the reliability of the results and accomplish the set purpose, the following specific objectives have been pursued:

1. To determine the role of financial regulation as a factor in the economic security of the Russian Arctic.

2. To examine the features of the financial regulatory system

3. To study changes in budgetary legislation that contribute to the increase in the financial sustainability of the Arctic regions.

4. To assess the level of control over the use of local budget funds (using the example of an Arctic region, namely, the Murmansk region).

5. To assess the possibilities for improving the situation in the field of financial regulation in the Russian Federation, which is one of the most important success factors in ensuring the economic security of the Russian Arctic.

\section{RESEARCH MATERIALS AND METHODS}

The theoretical and methodological base is represented by the works of well-known Russian scientists, whose studies are devoted, among other things, to exploring the problems of organizing financial regulation as one of the most significant factors in ensuring the economic security of the Russian Arctic. The present study is also based on the application of a system approach and the methods which allow ensuring the conceptuality of the work as a whole, namely: the method of theoretical generalization, content analysis of the legislative and regulatory framework, monographic method, analysis and systematization, which allows us to get a more accurate picture of the aspects of financial regulation implementation in the Russian Federation and its impact on ensuring the economic security of the Russian Arctic. The information basis for this study has been the legislative and regulatory acts presented on the official state portals, official documents of the Government of the Russian Federation, the Government of the Murmansk Region, the Committee for State and Financial Control of the Murmansk Region, Internet resources, etc.

\section{RESEARCH RESULTS}

The result of the study is the identification of the features of the legal framework for financial regulation implementation in the Russian Federation in order to reduce external and internal threats to the economic security of the Russian Arctic and ensure the financial security of the state. It has been established that the organization of measures aimed at ensuring control and supervision functions over the compliance with the budgetary management procedure eventually makes it possible to use budgetary funds more efficiently and economically, to explore possibilities for using internal reserves of an organization, to increase the level of financial discipline and the sustainability of the economic system as a whole, which ultimately has a positive effect on ensuring the economic security of the constituent entities of the Russian Federation

\section{Discussions OF THE RESUlTS}

The role of financial regulation as a factor of the economic security of the Russian Arctic is to ensure the most effective and optimal organization of such state policy areas as budgetary, financial, tax, customs ones, and a number of others. This is expressed through the implementation of measures for the effective use of financial resources in various sectors of regional economy and the formation, on this basis, of a synergistic effect in ensuring the economic security of the entire Russian Arctic. In this regard, goal-setting should be considered as an important aspect. This means that the goal and the result should not be contradictory, they should be consistent with each other and interrelated.

The financial regulation system itself is based on certain standards which are the benchmark or starting points for the implementation of certain actions. Those negative processes that are currently taking place in the economy of the Arctic regions and the country as a whole (sanctions, the decline in economic performance due to the COVID-19 pandemic) objectively require increased efficiency of the use of public (municipal) resources, resulting in the necessity to revise some approaches previously used in the field of control over budgetary funds at the disposal of federal, regional, and municipal (local) authorities.

Financial regulation in the Russian Federation is governed by a number of legal norms which are provided for in the Budget Code of the Russian Federation [19], as well as in other legal acts. In the study of the regulatory framework of financial management, it is necessary to consider some of the features of the legal regulation of the activities of financial control agencies in the Russian Federation. Thus, there are several main areas: external and internal state (municipal) financial control, departmental control, internal control of institutions.

External state (municipal) financial control is carried out on the basis of the application of the following regulations: Article 268.1 of the Budget Code of the Russian Federation; Federal Law No. 6-FZ of February 07, 2011 "On General Principles of Organization and Activities of the Control and Accounting Bodies of Constituent Entities of the Russian Federation and Municipal Entities" ; Federal Law No. 41-FZ of April 05, 2013 "On the Accounts Chamber of the Russian Federation", as well as laws or decisions that are made at the level of certain subjects of law, or in other words - public legal entities, that is, constituent entities of the Russian Federation and municipalities [20].

Internal state (municipal) financial control is carried out on the basis of the application of the following regulations: Articles 269.1, 269.2 of the Budget Code of the Russian Federation; Resolution of the Government of the Russian Federation No. 1092 of November 28, 2013 "On the procedure of implementation of authorities by the Federal Service for Fiscal and Budgetary Supervision in control over finance and budgetary sphere"; Order of the Ministry of Finance of the Russian Federation No. 18n of March 20, 2014 "On Approval of the Administrative Regulations for the Execution of the State Function of Control in the Financial and Budgetary Sphere by the Federal Service for Financial and Budgetary Supervision"; Resolution of the Government of the Russian Federation No. 703 of December 1, 2004 "Regulations on the Federal Treasury"; legislative and regulatory acts that are adopted at the 
level of constituent entities of the Russian Federation and municipalities [20].

Departmental financial control is carried out on the basis of the application of the following regulations: Article 160.2-1 of the Budget Code of the Russian Federation; Order of the Government of the Russian Federation No. 89 of February 10, 2014 "About Approval of Rules of Implementation of Departmental Control in the Sphere of Purchases for Ensuring Federal Needs"; Order of the Government of the Russian Federation No. 193 of March 17, 2014 "About Approval of Rules of Implementation by the Main Managers (Managers) of Means of the Federal Budget (the Budget of State Nonbudgetary Fund of the Russian Federation), Chief Managers (Administrators) of the Income of the Federal Budget (the Budget of State Non-budgetary Fund of the Russian Federation), Chief Managers (Administrators) of Sources of Financing of Federal Budget Deficit (the Budget of State Nonbudgetary Fund of the Russian Federation) of Internal Financial Control and Internal Financial Audit and about Modification of Item 1 of Rules of Implementation of Departmental Control in the Sphere of Purchases for Ensuring the Federal Needs Approved by the Order of the Government of the Russian Federation No. 89 of February 10, 2014"; Order of the Ministry of Finance of the Russian Federation No. 146n of December 25, 2008 "About Ensuring Activities for Implementation of the State Financial Control"; the orders which were issued by the relevant departments [20].

Internal financial control of institutions is carried out on the basis of the application of such regulatory and legal acts as the Budget Code of the Russian Federation; the Federal Law No. 402-FZ of December 6, 2011 "On Accounting"; the Federal Law No. 7-FZ of January 12, 1996 "On Non-profit Organizations"; the Federal Law No. 174-FZ of November 3, 2006 "On Autonomous Institutions"; order of the Ministry of Finance of the Russian Federation No. 157n of December 1, 2010 "On approval of the Unified Chart of Accounts and Instructions for its Application"; Instruction on the Procedure for drawing up and submitting budgetary reports, which was also approved by the Order of the Ministry of Finance of the Russian Federation No. 191n of December 28, 2010; Instruction about Procedure for creation, submission of accounting records of the public (municipal) budget and autonomous institutions (approved by order of the Ministry of Finance of the Russian Federation No. 33n of March 25, 2011); Administrative regulations (approved by order of the Ministry of Finance of the Russian Federation No. 18n of March 20, 2014); Rules approved by the Order of the Government of the Russian Federation No. 1092 of November 28, 2013; special standards for internal and departmental auditing [20].

Currently, there are a number of amendments in the Budget Code that affect, in particular, paragraph 3 of Article 269.2. The information contained in this Clause concerns the issues of standardization of the implementation of internal state (municipal) control. Furthermore, there are additions regarding the powers of the authorities entrusted with the responsibility for approving standards related to such issues as the implementation of measures to ensure internal financial control of public (municipal) authorities. Thus, the processes associated with ensuring the economic security of the Russian Arctic are accompanied by an improvement in the conditions for the implementation of financial regulation aimed at increasing the efficiency of the use of financial resources at the level of constituent entities of the Russian Federation in a manner consistent with the observance of the rule of law, the conditions for their formation and distribution by regional and local authorities.

The unified methodology of financial regulation involves the use of a number of financial control methods, including performance auditing which makes it possible to assess the level of performance in the management of public financial flows. At the same time, there is a difference between a performance audit and a financial audit. A performance audit is focused on identifying facts of non-compliance with legal norms, poor management of financial and other material resources at the level of constituent entities of the Russian Federation and municipalities. In addition, a performance audit is focused on early recognition of problems and identification of deviations in order to be able to respond to them in time and take appropriate measures on short notice.

Consideration should also be given to a number of amendments to the Budget Code, which can significantly reduce the number of violations regarding budget funds use. Indeed, Clause 3 of Article 69.2 has been amended regarding the improvement of conditions for the implementation of interbudgetary relations. Financial sustainability in municipalities should be ensured by the fact that state (municipal) assignments should not contain annexes that lead to the arising of grounds for increasing expenditure obligations on the part of the subjects of the Russian Federation (municipalities). This is especially relevant to the Arctic regions where expenditure obligations are usually higher than the national average. Since, for example, there are costs related to the transportation of school children over sufficiently long distances, which has become a serious problem for many municipalities. Municipalities received vehicles for transporting children, while the costs of maintaining these vehicles were not provided. Local authorities had to turn to higher structures for providing additional funding [19].

The Budget Code clarifies Article 269, which contains a list of amendments defining the goals and types of state (municipal) financial control. The purpose of financial control is ensured through the implementation of measures aimed at compliance with the budget law of the Russian Federation, as well as other regulatory legal acts that ensure the order and regulation of legal relations in the budgetary sphere.

According to the content of Article 265 of the Budget Code, it follows that, in general, financial control can be of four types, for example, external or internal, preliminary or subsequent [19].

External financial control is exercised by the Accounts Chamber of the Russian Federation, internal financial control by the Federal Treasury. Prevention and suppression of violations of budget laws are implemented with the help of preliminary control, and subsequent control is carried out based on the results obtained from the use of financial flows of the budgetary system of the Russian Federation [19]. Ultimately, effective financial control implies the creation of such a reliable system that will ensure the safeguarding of financial resources, while at the same time increasing the responsibility of those who are empowered to manage budget funds.

Within the framework of the budgetary system, the provision of subsidies and grants to the budgets of the 
constituent entities and municipalities is significantly optimized, which makes it possible to use the allocated budgetary funds of all levels strictly for their intended purpose. The same goals are pursued by the addition to Clause 1 of Article 93.3, which contains information that the constituent entities of the Russian Federation that received a loan from the federal budget do not have the right to place it on deposits with a maturity of more than one month [19]. This amendment is aimed at reducing the debt overburden of constituent entities of the Russian Federation. For the Arctic regions, this problem is also significant, therefore, state bodies, including the Ministry of Finance of the Russian Federation, are taking measures to address this issue.

Another important issue of financial regulation is methodological support. For these purposes, amendments were made to a number of Articles of the Budget Code of the Russian Federation. Clause 3 of Article 157 contains information about the Federal Service for Financial and Budgetary Supervision, vested with powers to analyze the implementation of budgetary powers. That is, this service is obliged to analyze the causes of violations, embezzlement of public funds, and other abuses. At the same time, this amendment does not reflect penalties for such violations. The unified methodology of the budget classification of the Russian Federation is contained in Clause 23 of Article 165. This methodology implies the implementation of such a systematic (comprehensive) financial analysis, which is difficult to conduct in the absence of a methodology for the formation of statistical reporting on public finances. The scientifically based methodology allows not only ensuring budget savings, but, ultimately, creating conditions for ensuring the economic security, both of the Russian Arctic and the state as a whole. Article 165 of the Budget Code of the Russian Federation defines the relevant institution - the Ministry of Finance of the Russian Federation, which is responsible for the development of methodological support for internal financial control and audit. Also, within the framework of the same addition, a list of actors and organizations that are subject to oversight is established. At the same time, the issues related to the definition of measures of responsibility and punishment for violating financial discipline, which does not provide conditions for its observance, have remained insufficiently considered.

In such an Arctic region as the Murmansk Region, financial regulation issues are managed by the Committee for State and Financial Control of the Murmansk Region.

For 9 months of 2020, the Committee for State and Financial Control of the Murmansk Region carried out 41 (5 scheduled, 36 unscheduled) monitoring activities for compliance with the requirements of Federal Law No. 44-FZ of April 5, 2013 "On the contract system in the field of procurement of goods, works, services to ensure state and municipal needs"'[6]:

- 32 audits of the key budget institutions of the region and their subordinate institutions (hereinafter referred to as state customers);

- 9 audits of the customers of Murmansk region municipalities (hereinafter referred to as municipal customers).

According to the results of the audits (Fig. 1) of the state and municipal customers of the Murmansk region, 261 violations of the procurement legislation were revealed [21]
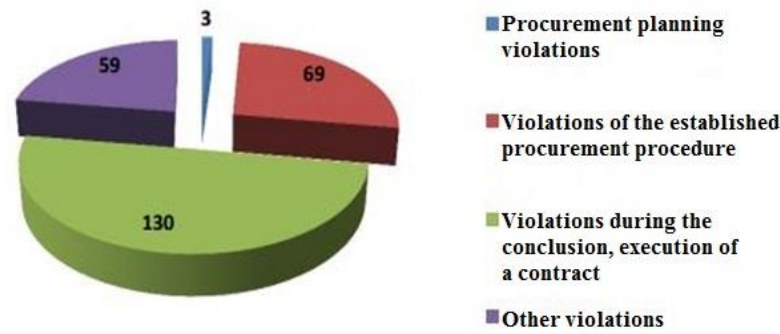

Fig. 1. Shares of all revealed violations by their types, units [21]

It should be noted that the least number of violations were related to procurement planning, which is conditioned by the amendments introduced during 2019 to Law No. 44-FZ regarding simplifying procurement planning procedures. Therefore, the number of violations identified at this stage of procurement has sharply decreased.

The most common violations are when concluding and executing a contract. The majority of violation cases are related to the delays in reporting information and submitting documents on the conclusion, modification, and execution of contracts ( $31 \%$ of all violations), another reason is the change in the essential terms of a contract in cases not established by the legislation in the field of procurement (13.4\%) [21].

In general, the presence of the majority of the violations is related to a number of systemic problems that demonstrate insufficiently effective control by public authorities or local self-government bodies, which are budget funds managers. This indicates both non-compliance with the budget legislation, relevant internal budget procedures and standards, and poor insufficiently effective control over the activities of subordinate institutions.

The certificate of the Committee for State and Financial Control of the Murmansk Region on the audits for 2020 does not indicate whether, in addition to recommendations for eliminating shortcomings, any measures of influence related to personal responsibility were taken afterwards. Since the observance of mandatory legal norms and principles of control over ensuring state (municipal) interests is one of the most significant factors in preventing various kinds of abuse and corruption.

In addition to changes in the budget legislation, a number of provisions of the Civil Code of the Russian Federation have also changed over the past three years. First of all, the changes affected the following Articles: Article 555 on "Price in the Contract for the Sale of an Immovable", Article 654 regarding "The Amount of the Rental Payment", Article 1234 regarding the "The Contract of Alienation of an Exclusive Right", Article 1235 on a "License Contract" [22].

\section{CONCLUSIONS}

Based on the foregoing, it is apparent that the system of financial regulation in the Russian Federation is implemented through the application of law, first of all, financial law. Financial regulation in the Russian Federation is implemented through the legal framework applied to budgetary funds recipients who execute state and municipal contracts. At the same time, supervision and control measures are taken to ensure compliance with the rules for the implementation of settlement 
and financial transactions. This makes it possible to use budget funds more efficiently and economically, explore opportunities to use the internal reserves of an organization, increase the level of financial discipline, the stability of the economic system as a whole, which ultimately has a positive effect on ensuring the economic security of the constituent entities of the Russian Federation.

The analysis of some aspects of the application of the legal framework for the implementation of financial regulation in the Russian Federation, amendments to the Budget Code of the Russian Federation made it possible to consider a number of issues affecting the problems of ensuring the economic security of the Russian Arctic, ensuring control over the use of local budget funds. It has been established that many issues remain only partially resolved. For more effective financial regulation, it is necessary to establish cooperation between the lawenforcement system and the supervisory authorities exercising financial control. Solving this problem could help to reduce corruption and the total number of crimes in the economic sphere. In addition, it is necessary to ensure the segregation of revenue and expenditure sources in order to stabilize the situation in inter-budgetary relations between different levels of government, as well as create conditions that will provide opportunities for non-tax revenues of local budgets.

\section{Acknowledgments}

The study was supported by the RFBR project 20-01000776 A "Improving the state financial regulation of the development of the regions of the Arctic zone of the Russian Federation as the basis for ensuring the economic security of the Russian Arctic".

\section{References}

[1] W. Hager, Perceptions of Economic Security, Gesau: F.A.M, 2001

[2] C. Murdoch, Economics issuies and national security, London: Lawrence, 1997.

[3] Y. Jiang, "Economic Security: Redressing Imbalance", China Security, 2008, vol. 3(2), pp. 66-85

[4] L. Guro, "Bringing the economy back in: The political economy of security sector reform", Economics of Peace and Security Journal, 2013, vol. 8(2), pp. 35-43

[5] C.R. Neu, and Ch. Wolf, The Economic Dimensions of National Security, Santa Monica: National Defense Research Division, RAND, 1994.

[6] A. Ocepek, 2010 Economic security and the European dream. Marquette University, 2010.2 Retrieved from http://www.anselm.edu/Documents/NHIOP/Global\%20Topics

[7] N.G. Theriou, "Strategic Management Process and the Importance of Structured Formality, Financial and Non-Financial Information", European Research Studies Journal, 2015, vol. 18 (2), pp. 3-28.

[8] L.I. Abalkin, "Economic security of Russia: threats and their reflection" [Ekonomicheskaya bezopasnost' Rossii: ugrozy i ikh otrazheniye],
Economic issues, 1994, vol. 12, pp. 4-16. (In Russ.).

[9] S.Yu. Glazyev, "Economic security as a synonym for the competitiveness of the Eurasian Union" [Ekonomicheskaya bezopasnost' kak sinonim konkurentosposobnosti Yevraziyskogo soyuza], Eurasian integration: economics, law, politics, 2018, vol. 4, pp. 10-12. (In Russ.).

[10] A.I. Tatarkin, "Economic security as an object of regional research" [Ekonomicheskaya bezopasnost' kak ob"yekt regional'nogo issledovaniy], Economic issues, 1996, vol. 6, pp. 79-85. (In Russ.).

[11] A.I. Tatarkin, and A.A. Kuklin, "Changing Paradigm of Region's Economic Security Research" [Izmeneniye paradigmy issledovaniy ekonomicheskoy bezopasnosti regiona], Economy of Region, 2012, vol 2, pp. 25-39. (In Russ.).

[12] V.S. Selin, Economic security of the Russian Arctic: features an problems of support [Ekonomicheskaya bezopasnost' rossiyskoy Arktiki: osobennosti i problemy obespecheniya], Apatity, publishing house of KSC RAS, 2018. (In Russ.)

[13] M.V. Ulchenko, "Analysis of the economic security of the European part of RF North" [Analiz ekonomicheskoy bezopasnosti Yevropeyskoy chast Severa RF], North and market: formation of the economic order, 2014 vol. 6 (43). pp. 59-64. (In Russ.).

[14] D.L Kondratovich, M.V. Ulchenko, and D.S. Krapivin, "Problems and prospects of increasing the level of economic security of the coastal Arctic regions on the basis of the European experience", IOP Conference Series: Earth and Environmental Science, 2019, vol. 302 (1), 012122.

[15] M.V. Ulchenko, R.V. Badylevich, and D.L. Kondratovich, "Specific features of ensuring economic security of coastal Arctic regions", IOP Conference Series: Earth and Environmental Science, 2019, vol. 302 (1), 012104 .

[16] R.V. Badylevich, Approaches to building a system of financial regulation of the development of Northern regions based on an assessment of financial potential [Podkhody k postroyeniyu sistemy finansovogo regulirovaniya razvitiya regionov Severa na osnove otsenki finansovogo potentsiala], in.: R.V. Badylevich, E.A. Verbinenko (Ed.), Apatity, publishing house of KSC RAS, 2019. (In Russ.).

[17] S. Kozmenko, A. Teslya, and S. Fedoseev, "Maritime economics of the Arctic: Legal regulation of environmental monitoring", IOP Conf. Series Earth and Environmental Science, 2018, vol. 180 (1), 012009.

[18] E.V. Voloshenko, and K.Yu. Voloshenko, "Evaluating and Measuring the Security of Russia's Border Regions: Theory and Practice" [Otsenka i izmereniye ekonomicheskoy bezopasnosti prigranichnykh regionov Rossii: teoriya i praktika], Baltic Region, 2018, vol. 10(3), pp. 96-118. (In Russ.).

[19] Reference legal system "ConsultantPlus". The Budget Code of the Russian Federation [Byudzhetnyy kodeks Rossiyskoy Federatsii]. (In Russ.). Retrieved from http://www.consultant.ru/document/cons_doc_LAW_19702

[20] A single portal of financial information for specialists of state institutions [Yedinyy portal finansovoy informatsii dlya spetsialistov gosuchrezhdeniy] (In Russ.). Retrieved from https://www.budgetnik.ru

[21] Official portal of the government of the Murmansk region. Committee for State and Financial Control of the Murmansk Region [Ofitsial'nyy portal pravitel'stva Murmanskoy oblasti. Komitet gosudarstvennogo i finansovogo kontrolya Murmanskoy oblasti] (In Russ.). Retrieved from https://gosfincontrol.gov-murman.ru/news/2020

[22] Reference legal system "ConsultantPlus". Civil Code of the Russian Federation [Grazhdanskiy kodeks Rossiyskoy Federatsii] (In Russ.). Retrieved

http://www.consultant.ru/document/cons_doc_LAW_5142 